\title{
Anthrovision
}

Vaneasa Online Journal

$6.2 \mid 2018$

Visual Anthropology From Latin America

\section{Mayan Justice Practices and Community Video}

Collaborative Visual Anthropology in Quiché, Guatemala

\section{Carlos Y. Flores}

\section{(2) OpenEdition \\ Journals}

Electronic version

URL: http://journals.openedition.org/anthrovision/3976

DOI: 10.4000/anthrovision.3976

ISSN: 2198-6754

Publisher

VANEASA - Visual Anthropology Network of European Association of Social Anthropologists

\section{Electronic reference}

Carlos Y. Flores, « Mayan Justice Practices and Community Video », Anthrovision [Online], 6.2 | 2018,

Online since, connection on 06 September 2019. URL : http://journals.openedition.org/

anthrovision/3976; DOI : 10.4000/anthrovision.3976

This text was automatically generated on 6 September 2019 .

(c) Anthrovision 


\section{Mayan Justice Practices and Community Video}

Collaborative Visual Anthropology in Quiché, Guatemala

\section{Carlos Y. Flores}

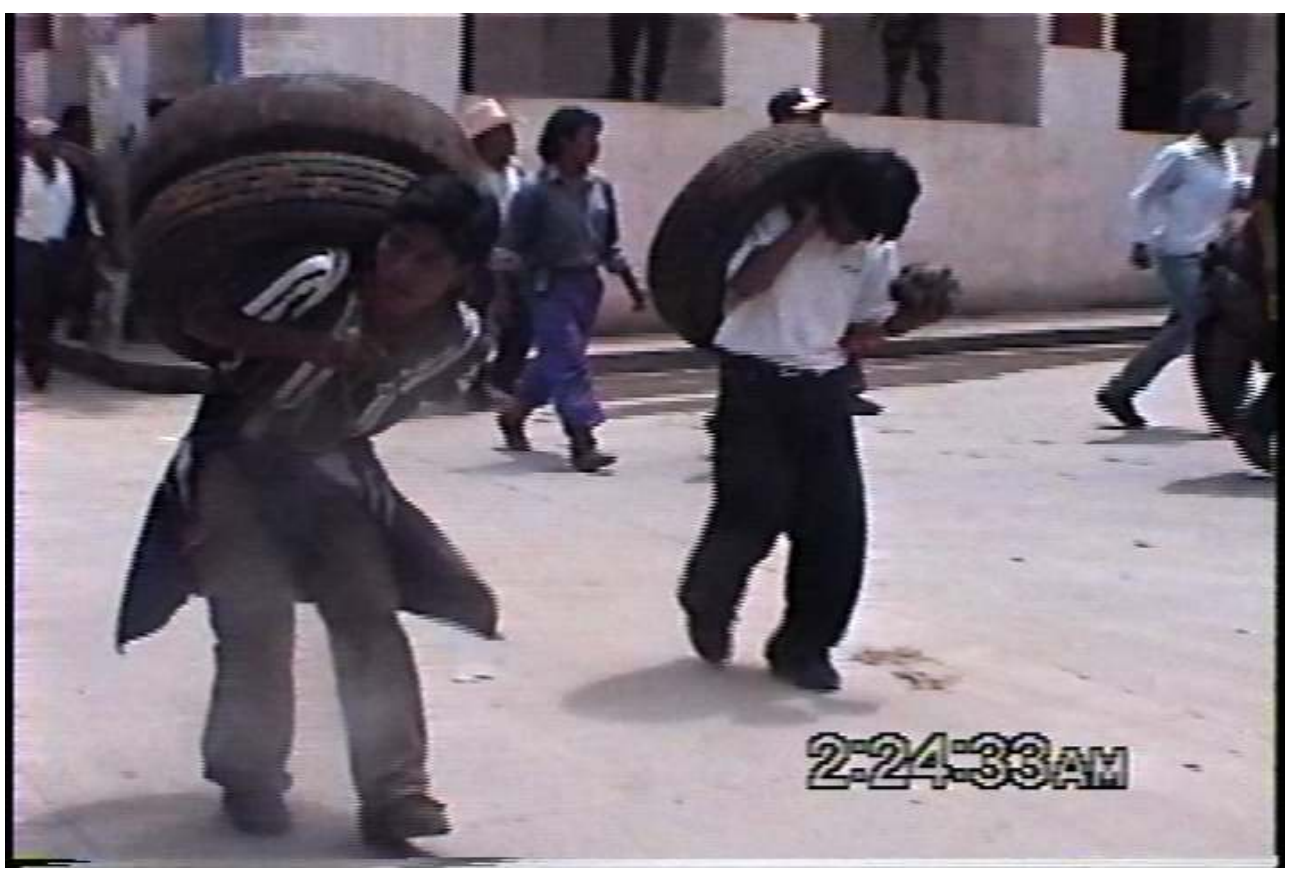

Still from original community video

\section{Introduction ${ }^{1}$}

Several years ago, in November 2006, Petrona Urizar, a 24 year old ladina (nonindigenous) woman sought the help of the office of the K'iche' Indigenous Defense in Santa Cruz del Quiché to secure justice for the murder of her husband, Manuel Salvador Urízar, by local hired killers a few weeks before in the village of Las Casas, San Andrés 
Sajcabajá. Petrona had already gone to the police and the public prosecutor's office but had failed to obtain the capture much less the trial of those responsible. Another two ladina widows from the village accompanied Petrona to the K'iche' Indigenous Defense: their husbands had also been murdered some months previously, supposedly by the same group. The underlying issue seemed to be related to a family dispute over land and access rights.

After initiating investigations, activating their extensive social networks across the region, in less than a week this Mayan defense organization detained three individuals, including Juan Ajeataz, a k'iche' neighbor from Choacamán, a nearby village, who was known to be a hired killer. A fourth suspect, Alejandro Castro Tipaz, was in hospital, having received various machete blows from the desperate victim before he died from gunshot wounds. Petrona, now a widow, had witnessed the entire event, with one of her four children in her arms.

In public assemblies with local villagers and indigenous authorities the suspects finally confessed to their participation in the killing, but only after they had mutually incriminated themselves. The singularity of this case was that both the confessions and the process followed by Mayan justice were captured in videos recorded by local volunteers supporting the indigenous mayors. Years later this audio-visual record, one amongst many filmed by indigenous villagers in popular trials carried out according to Mayan law, had implications far beyond the locality of Santa Cruz del Quiché, as they were subsequently used for the strengthening of Mayan community justice, within the official justice system, ${ }^{2}$ and later through anthropological research.

4 The aim of the present article is to discuss the uses of video within indigenous legal procedures in the region, together with the possibilities and limits of a collaborative anthropological project that was made possible once we acquired the video footage and textualized it following community member's understandings and judicial needs. Additionally, the invitation securing our involvement was also motivated by a clear political interest shaped by the indigenous authority's efforts to gain not only influence and legitimation among their own communities, but also within the dominant ladino state. This was part of the permanent dispute of spaces of sovereignty in a society characterized by acute ethnic and class inequalities. Especially relevant here are the ways in which the original video materials were re-signified over time and space when other actors, including ourselves, intervened in their re-use, negotiation and (re)interpretation.

\section{Anthropology and the Rediscovery of the Community Video Archive}

5 Some years after the events described above, Rachel Sieder, a researcher who had worked for a number of years on legal pluralism and indigenous law in Guatemala, shared with me in Mexico City an archive of videos in 8 and Hi-8 format which had been loaned to her by Juan Zapeta, the indigenous mayor of Santa Cruz del Quiché, on her most recent trip to that country. Zapeta had told her then that community members had recorded most of the videos with a camera that his son, who lived in the USA, had sent to the family as a present. "I think they'll be interesting for your work" he had told her. 
6 After locating an old Hi-8 camera, we both reviewed the material, and although we didn't understand most of the deliberations recorded in the tapes -almost all were in the k'iche' language which neither of us speak - we could immediately see the importance and richness of the filmic archive, given the strength of the testimonies and events recorded. The images filmed by non-professional indigenous cameramen showed some 50 hours of proceedings, often incomplete, of communal resolution of different inter and intra community and family conflicts, including cases of robbery, rape or attempted rape, murder or attempted murder, destruction of guns, slander, problems with land delimitation, conflicts over water use and disputes about access or rights of passage. These exercises in "Mayan law" had been carried out since the start of the 2000s in a collaboration between a local civic association called the Indigenous K'iche' Defense ${ }^{3}$ and indigenous mayors in the municipality. Amongst the videos was the case of Petrona Urizar.

7 The region where the videos were made, one of the most hard-hit by the civil war of the 1980s, was characterized by high levels of social violence and criminality, and scant access to state justice for the local population. This state of affairs had contributed to a widespread practice of collective punishments without any type of judicial process, including beatings and lynchings of dozens of criminals or suspected criminals. ${ }^{4}$ The visual materials Rachel Sieder and I examined seemed to contradict such extreme punitive practices, demonstrating instead how some local groups and their leaders were making great efforts to develop or reconstruct forms of political and social organization in order to mediate the conflicts that arose on a day to day basis. These initiatives not only signalled the existence of alternative forms of dispute resolution, but also local ways of counteracting brutal forms of collective punishment with mechanisms that also appeared to be more conciliatory, restorative, efficient and collective than state law.

8 Once back in Santa Cruz del Quiché we talked with Juan Zapeta and other indigenous authorities and proposed the production of two formal documentaries based on the films they gave us, which they enthusiastically accepted. We started to work straight away. The method we followed was relatively simple in design, although more complex in implementation: identifying those individuals within the film recordings who had played a key role in the proceedings and then trying to find and interview them to record their views and reflections years after the events originally filmed had taken place. We believed that although the documentary would be mediated by our interventions, we should try as much as possible to maintain an emic perspective, the vision from within the community, which was contained in the original recordings.

9 When (through Juan Zapeta) we managed to locate some of the participants in the trials in order to interview them, some were willing to talk on camera but others gave us evasive responses as a friendly way of saying no. However, the key element in this process of negotiation was being able to work with the indigenous mayors, who commanded prestige, confidence and respect within the rural communities of Santa Cruz del Quiché. The mayors had become important mediators in numerous local conflicts, which had in turn allowed them to consolidate significant legitimacy and power in the region. Even so, these mediators faced certain limits - sometimes their very presence led people to refuse to participate in the filming, revealing divisions in the local social and political landscape and the fact that not everyone endorsed their methods and forms of communal justice, or their political tendencies. Nonetheless, generally following brief presentations explaining 
our motivations and the reasons we believed their participation was important, most of the potential interviewees agreed to be filmed for the documentaries.

After we had recorded most of the interviews we began to edit the original and the newly filmed materials together, producing an initial cut of what would become the first documentary about three young truck thieves (K'ixba'l - Shame: $37 \mathrm{~min} ., 2010$ ). As is the situation in any process of textualization -in our case shifting from real time to cinematographic time- the far-from-simple task of reducing hours of footage to the most essential elements meant we had to position ourselves within both the local social and political context and within certain anthropological debates. We agonized about which elements we should give more emphasis to: the more "judicial" dimensions of the processes or the elements of indigenous "cosmovision" or worldviews expressed by the participants; the precise details about the robbery, or the broader ideas expressed by the interviewees about law and justice. We were conscious of the enormous responsibility weighing on us, given that the conceptual framing of the material in the video documentary would inevitably reframe and determine to a certain extent the nature of the subsequent debate, changing considerably what had gone before.

11 The challenge of interpreting the events recorded in the video-tapes was part of a complex intercultural interaction. In order to reach wider audiences, our representations needed to rely on hegemonic conventions and codes of intelligibility which did not necessarily accurately translate or interpret the original understandings (see Said 1995: 22, Hall 1997: 11). Locating the visual material within broader conceptual frameworks, where they acquired a new value ${ }^{5}$ also risked distorting their original, more local essence, placing them within a sphere of more conventional or universalist understandings and readings in order to be accepted within hegemonic imaginaries.

However, the most important validation came from the indigenous mayors, who saw the first cut with us and with whom we maintained a rich debate about the final editorial decisions. ${ }^{6}$ At one point on seeing the first cut of the first documentary, Juan Zapeta remarked "this material is going to be very controversial", particularly referring to scenes depicting the xik'a'yes or public ritual whipping administered to the three transgressors. I asked him whether we should stop the documentary or have a rethink. He responded emphatically: "no, let it be controversial. That's how it happened, that's the truth. We want there to be debate, we want people to know how we work and why..." 
Intercultural editorial meeting

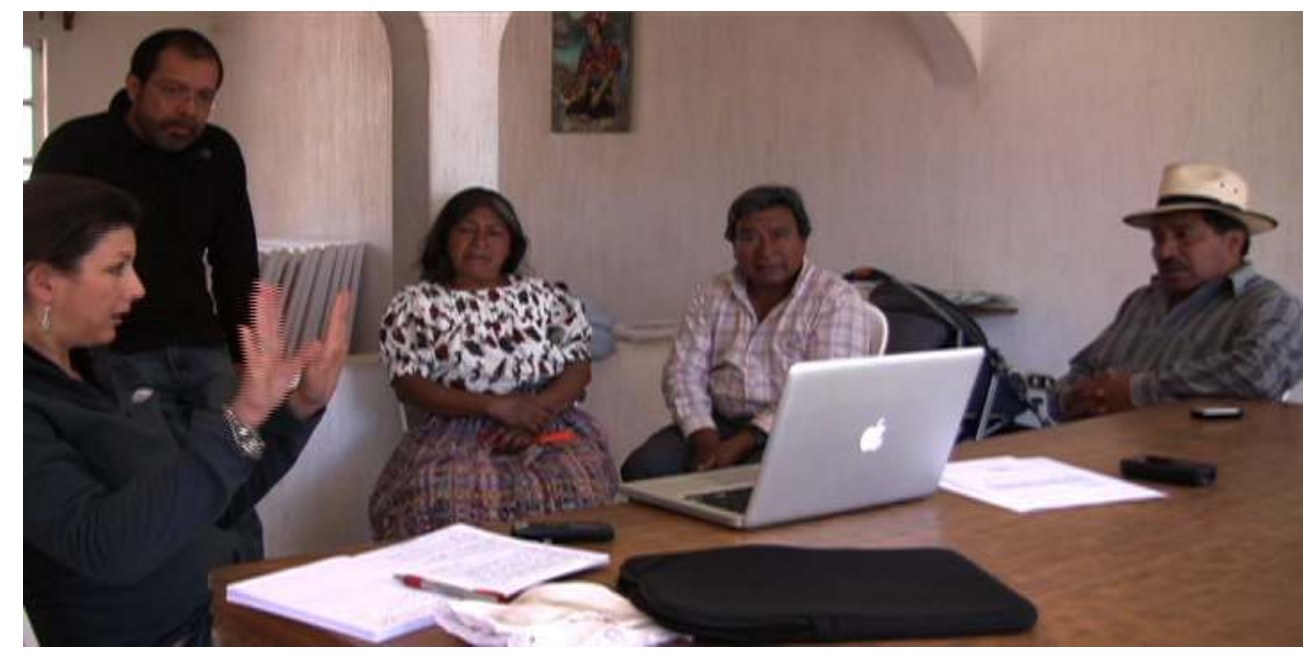

Photo by Carlos Y. Flores

\section{The Logics of Mayan Law in the Appropriation of Video}

Versions and interpretations of reality are always multiple, particularly in societies as fragmented and conflictive as Guatemala. The indigenous authorities understood that their prospects of convincing different audiences depended on their versions of events being as incontrovertible as possible. Ultimately the legitimacy and success of autochthonous legal practices within indigenous communities relies on the construction of consensus from below. This involves the development of micro-hegemonic local discourses intended for consumption within the community, but also within the nation or vis-à-vis official law, both of which are dominated by non-indigenous sectors of Guatemalan society.

K'iche' leaders watching "Two Justices"

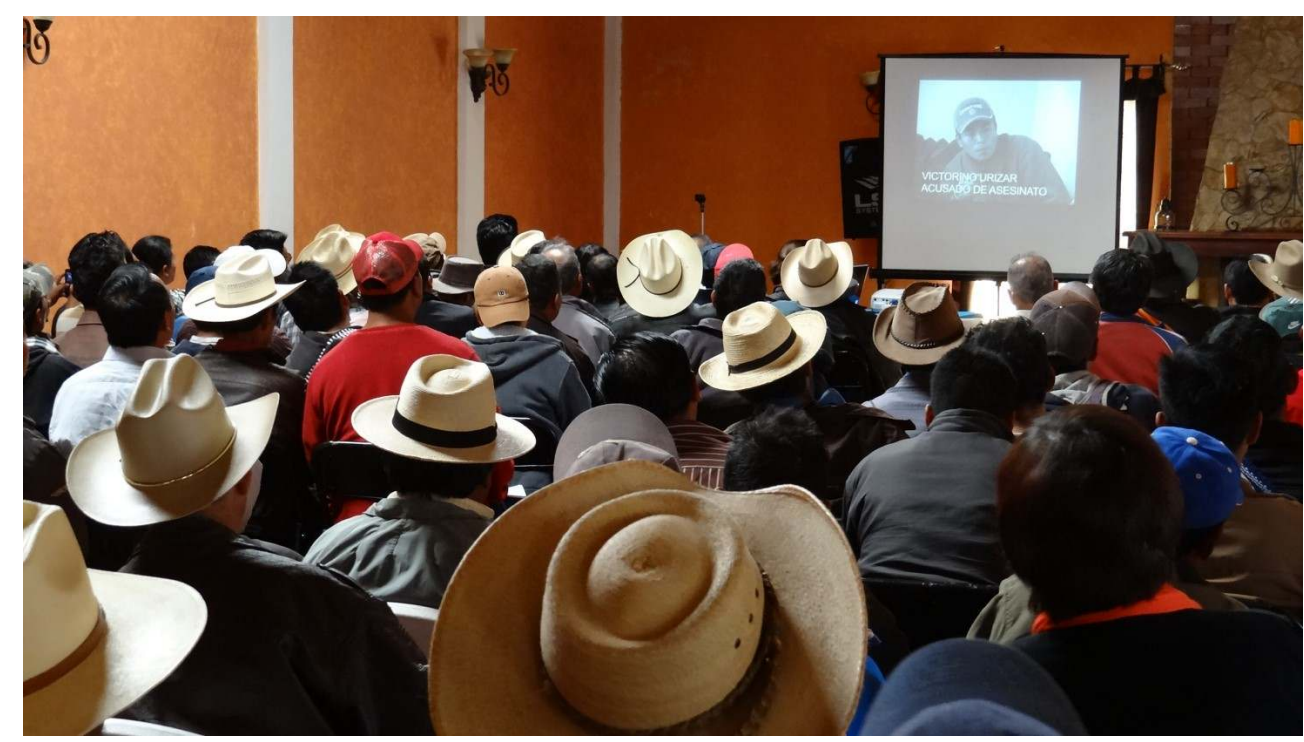

Photo by Carlos Y. Flores 

especially one that records "real time", constitutes an empirical demonstration of truth because the events registered on film "don't lie," even though people and especially those accused of wrongdoing can certainly do so. From this operational context, issues such as intentionality, directionality and selectivity in the use of the camera are not at issue, as it would have been within an academic environment where filming itself constitutes a form of textualization. For the indigenous authorities its importance lies in the fact that it is possible to show, and thus to validate, a legal proceeding "just as it really happened." When we interviewed the indigenous mayors in an effort to understand the different local logics at play in particular cases, they frequently told us "just like it is in the recording [we did one thing or another]", invoking this evidence of "the truth" in order to reinforce their political and moral authority. ${ }^{7}$ criminals and the procedures applied to them during the communal assembly. Here, the potential always exists for things to get out of control, with some people demanding beatings or lynchings. ${ }^{8}$ Given the histories of violence in the region, some sectors of the population undoubtedly support this kind of extreme summary justice. However, at the same time it is practically impossible to find anyone who openly defends such acts or admits to having participated in them. Collective assassinations, apart from being prohibited by state law, are also disliked within the broader social imaginary as they are considered shameful and irrational individual or collective acts. For this reason it is very rare to find visual registers of such events (although these do exist), ${ }^{9}$ because no one promoting this kind of "solution" wants to be photographed, recorded or identified in a video, most of all at the moment that the person or persons captured are being summarily executed. Groups of neighbours who carry out such acts are, as Helene Risør argues for the case of El Alto, Bolivia, "a faceless entity carrying out mortal violence" (2010: 465).

Although anonymity is the norm, the symbolic register of these vigilante actions ${ }^{10}$ is always present in the collective consciousness. Information about bodies which appear with signs of torture, or lynchings, flows constantly between individuals, social networks or the communications media. Such acts of violence occur outside the sphere of any official or semi-official control, such as NGOs or religious groups. In effect they constitute arbitrary abuses against the civilian population and can even acquire a paramilitary quality within a context where social violence is highly naturalized. In other words, as María Teresa Sierra observes, "weak state hegemony accompanied by the absence of the rule of law combined with fragile systems of indigenous justice provides fertile ground for the proliferation of violence and extra-legal justice practices." (Sierra 2004: 26).

On the contrary, the visual recordings by community members provide a degree of security and procedural guarantees for those who promote and participate in forms of community justice which do not involve the death of those accused. It is very important for the indigenous mayors who apply Mayan law to make their work known to a wider public in order to gain social and political legitimacy, both within the local environment and beyond. In fact, the official rejection of lynchings has led state justice officials in Quiché to form operational alliances with the indigenous mayors precisely because the latter have demonstrated a great capacity to defuse potential lynchings and reduce the incidence of such acts of violence (see Padilla 2008: 158). Within these volatile contexts the indigenous mayors have to a certain extent become interlocutors and valued 
collaborators of the state justice system. This is because their effectiveness in resolving cases without resorting to extreme measures such as the murder of those accused has gained them widespread public support.

Inside these highly disputed contexts of security/ insecurity, the indigenous mayors work constantly to stabilize and expand consensus amongst the population that supports them. For this reason they constantly invoke symbols and instruments which provide them with legitimacy and, more importantly, which support their claims to be operating within national and international legal norms. For example, they appeal to International Labor Convention 169, ratified by Guatemala in 1996, which guarantees indigenous peoples rights to exercise their own forms of law. Similarly, they invoke the peace agreement on the Identity and Rights of Indigenous Peoples, signed between the government and the guerrilla in 1995 as part of the peace settlement. This committed the Guatemalan state to recognize, respect and promote indigenous forms of law and their community leaders. In other words, the indigenous mayors resort to a strategic use of state law and international human rights law in order to emphasize the legality of their exercise of Mayan law, in the knowledge that this is also subject to respect for fundamental human rights guarantees. As Sierra observes, "state legality has penetrated and structured indigenous law, generating processes of interlegality and legal pluralism. It is impossible to talk about self-contained or wholly separate justice systems." (Sierra 2004:13). ${ }^{11}$ Or as a former community mayor and supporter of Mayan law in Quiché affirmed:

Thank God we have the Convention [169], the Constitution, and the rights of indigenous peoples. These are tools we have to know how to use, because I can do many things and defend my actions according to the Convention, but if I do them badly then there will be consequences..." (Julián León Zacarías, interview 10 July 2010).

In Santa Cruz del Quiché the videos have become a kind of pedagogic aid not just to explain and educate the population about the ways in which complicated cases of conflict within the communities have been resolved, but also to build political consensus and moral community. According to Juan Zapeta, the practice of Mayan law seeks not only to process and sentence those who break community norms, but also to consolidate spaces for peaceful coexistence and social order by showing "what is bad and what is good, what's right and what's wrong." These moral claims reflecting understandings about law, community life and justice are somehow amplified by the audio-visual recordings. Here an emphasis is also placed on the specific cultural nature of Mayan law, as it is on the basis of claims to ethnic difference that national and international law sanctions spaces for indigenous peoples' exercise of their own forms of law within multicultural societies. ${ }^{12}$

Inside this multicultural context, the value of certain elements such as confession or acceptance of responsibility is highly valued within Mayan law, as it is seen as the first step towards repentance and a change in behaviour from criminality to a dedication to work. However, in state law the principle of the presumption of innocence means it is the state itself which must demonstrate the guilt of those accused. Therefore, in Mayan law a confession is seen as something potentially positive for both accused and victim, in contrast to state law where confession -accompanied by supporting evidence- normally leads to conviction and a prison sentence (see Padilla 2008: 169-70).

Within Mayan law the ideal long term solution involves the repentance of those guilty of crimes or misdemeanours and their full rehabilitation and reincorporation inside the community. As indigenous mayor María Lucas stated, "What we want is for them to be 
straightened out" (interview April 2009, translated by Juan Zapil). Following the transgression of community norms and the ensuing crisis, indigenous authorities normally try to repair the damage as a necessary first step towards social reintegration. However, as Victor Turner (1974) observed, reparation or correction is the least stable, most liminal or transitional of all the phases of a conflict (which include transgression, crisis, reparation, and reintegration). If it is insufficient or unsatisfactory then things can easily return to the previous stage of crisis without resolving the dispute which has generated what Turner called "the social drama".

Another level within the audio-visual recordings is that of the performativity of the practice of law. This theatrality, visible in the acts filmed and the body language and words of the participants, is an essential element of any legal system with public trials. Such trials function not simply to establish the guilt or innocence of those accused, but also to convince those participating in the event of the justice of the sentence. Establishing the truth, then, has to do with the behaviour and public performance of those accused and those who accuse them. Proof is not only based on concrete forms of evidence, but also on the extent to which the population believe the supposed transgressors. Within the context of Mayan law practiced in communities in Santa Cruz del Quiché, those accused are generally not strangers but rather known individuals whose behaviour and history can be already viewed as positive or negative by a community.

For Edgar de León, of the Guatemalan Association of Mayan Lawyers and Notaries, one of the reasons for the prevalence of Mayan law has to do with Mayan values:

Words have value......when we talk about communication, well I have to see the person who is talking to me, I have to look in his eyes, see his gestures, I have to understand his feelings and what someone is trying to say when they come to make a complaint. When this kind of communication exists a connection is immediately established between the authorities and the people who elected them as authorities.......Another important aspect is patience (in contrast to the state justice system, where time is measured out and if you forget something you can't go back and include it). In the Mayan justice system time isn't so constrained, the ability to listen is more important. We say that listening is like involving yourself in a problem at the moment the person is explaining it. We should remember that in human terms is a problem is never isolated; it involves feelings, and the histories of families and even entire communities. If the authorities aren't able to listen then communication breaks down. It's also important that the collectivity is part of the resolution of the conflict. In the state justice system there's a jury, but in the Mayan system it's not a jury but the communal assembly, the whole community is present and takes part. What is being asked of the community at that moment? That the fabric of the community should not break down. And lastly there is shame, in the community and amongst indigenous peoples, shame still exists (Edgar de León, public speech on the 20 February 2013, Santa Cruz del Quiché).

This familiarity with the community often provides the local cameramen with a degree of invisibility; indeed the participants in proceedings seem to pay little attention to them. In the case of the three young men accused of stealing the truck, it was clear that the cameraman recording the event made an extensive visual study of the reactions of those implicated. The recording revealed an effort to try and capture revelations and involuntary contradictions on the part of the three accused that could eventually give them away, such as furtive glances exchanged between them or close ups on their faces when they were being asked specific questions to try and establish their innocence or guilt. 


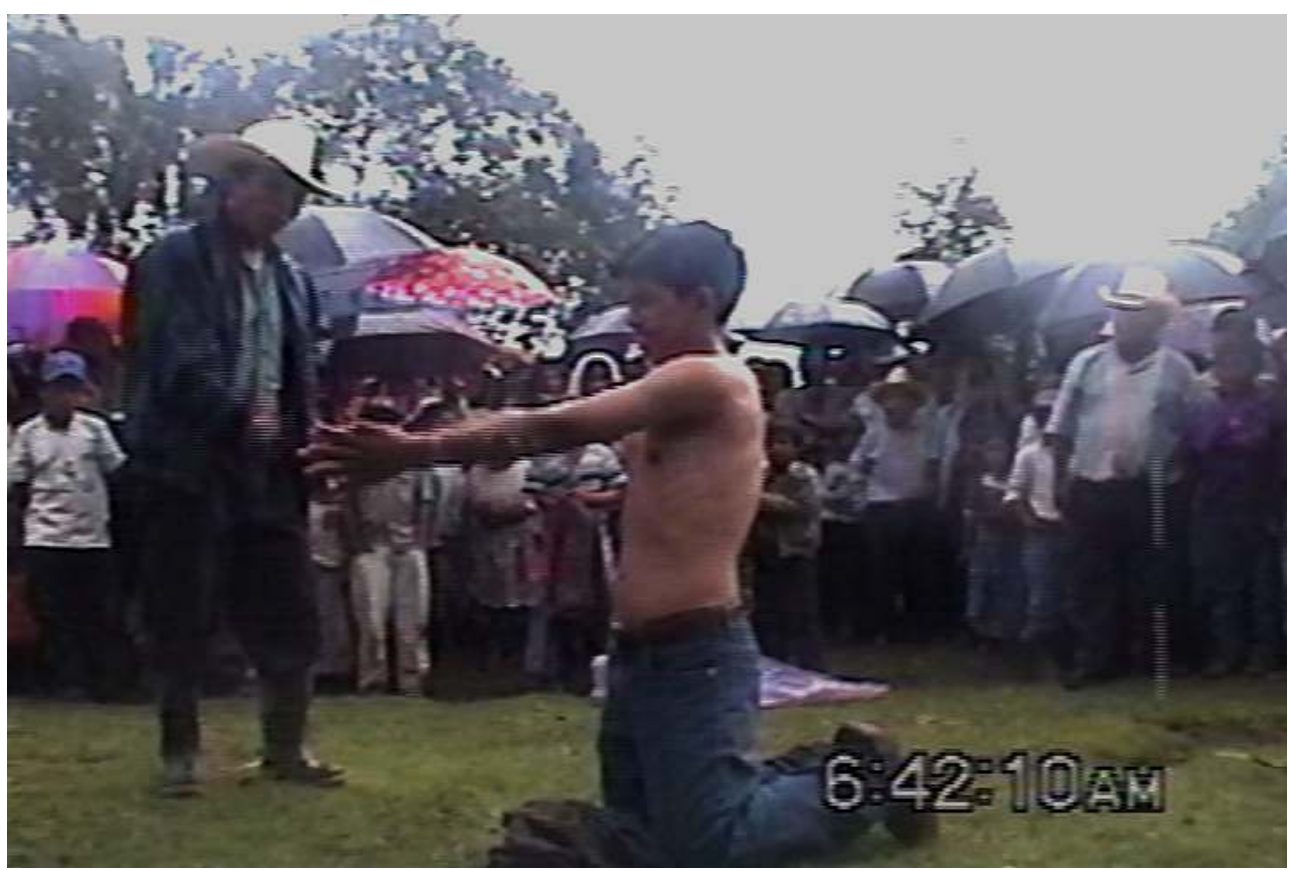

Still from community archive

The work of these cameramen, close collaborators of the indigenous mayors or sometimes even members of their families, constituted a powerful form of support for their practice of Mayan law in Santa Cruz del Quiché. Most of the footage in the video archive we received for the decade of 2000 had been filmed by Luis Eleno Zapeta and Mateo Zapeta Tzoy, the son and the cousin, respectively, of the indigenous mayor Juan Zapeta. Mateo Zapeta, in turn, is also the husband of the indigenous mayor María Lucas, an active and influential interpreter of Mayan law in Santa Cruz del Quiché. Between them they had formed a solid nucleus of familial and political allegiance which allowed them to work together and to reflect on their everyday practices. Each and every one of them maintained extensive links with broader social networks in the surrounding communities.

Finally, it is important to note that one of the main characteristics of Mayan law is its public and oral nature, but the use of audio-visual recordings about these practices has in effect become a kind of non-written record, or a way of establishing norms and procedures. Until recently, most exercises of Mayan law had only been registered in the collective memory. The cameraman, although in some senses just another witness, was able to unify an account of what was understood and experienced according to different perspectives in time and space. The participants remember varying details or interpret different things about the events, recollections which change over time according to their needs and circumstances. By contrast, the narrative of the video-maker is much more permanent and also somehow provides the illusion of being "above" or outside individual human emotions and actions. These registers therefore represented a means of establishing control over communal representations of truth and the making of history. ${ }^{13}$ 


\section{Final Reflections} documentaries, Juan Zapeta also hoped that our contacts, particularly within academic circles, would enable the experience of Mayan law in Santa Cruz del Quiché to transcend the local and find news forms of circulation within different spheres, thereby not only enabling broader audiences to understand some of the logics of Mayan law, but also securing greater social and political legitimation for such indigenous communal practices. As another local leader observed about our work "what you're doing is making visible the role of the indigenous authorities." (Edgar de León, public speech on the 20 February 2013, Santa Cruz del Quiché).

\section{Presentation of "Two Justices" at the Supreme Court}

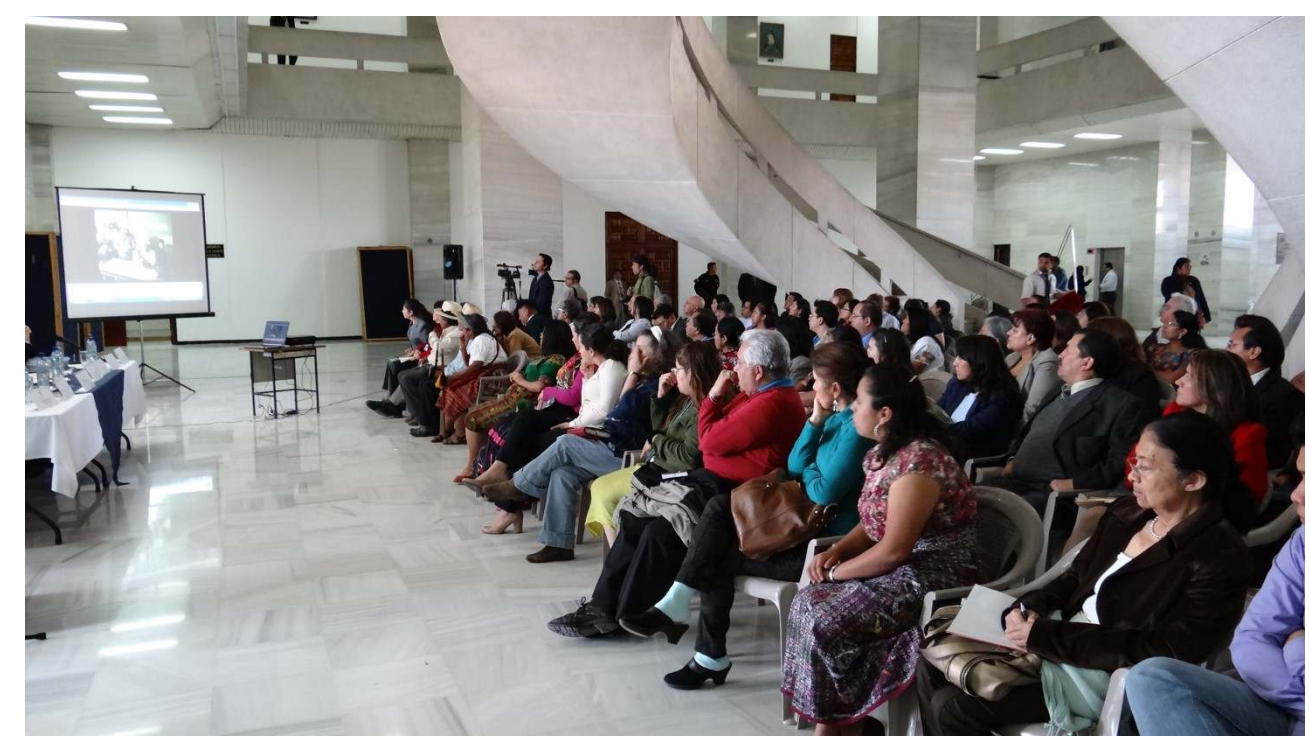

Photo by Carlos Y. Flores

According to this logic, the k'iche' leaders were reflecting processes increasingly common the world over whereby indigenous peoples are linking the local with the national and the global (sometimes referred to as glocal practices) in an attempt not only to gain greater recognition for their own forms of law, but also to secure spheres of sovereignty vis-à-vis the nation state (see Sieder 2011). George Marcus has coined the term "the activist's imaginary" to describe the ways in which subaltern groups are using video and other media tools to try and achieve broader emancipatory goals and social change, something which involves new challenges "about citizenship and the shape of public spheres within the frame and terms of traditional discourse on polity and civil society" (in Ginsburg et. al. 2002: 8). 
30 In many indigenous communities, the semi-autonomous spheres of Mayan law are the only effective alternative to confront and correct local wrongdoing, especially given the ineffectiveness of the Guatemalan justice system which in its current neoliberal permutation is promoting the privatization of security and justice (see Goldstein 2005), functions which have been assumed in different ways by individuals, communities and NGOs. Although in theory such a neoliberal dispensation makes it more feasible for indigenous authorities to gain legitimacy within a context of legal pluralism, such efforts are constantly eroded by nonindigenous national elites. In general semiautonomous forms of authority within indigenous communities have either been rejected or viewed as suspicious by the dominant political elite, the judicial apparatus of the state, economic elites and even by non-elite non-indigenous sectors.

31 The process of producing visual materials about exercises in indigenous law in collaboration with the indigenous mayors in Quiché, materials which were used for reflection and debate by different national and international actors, illustrated how the norms and practices of Mayan law sometimes clash with state law, at other times interact with it, and sometimes operate in separate, parallel spheres. These interactions seemed to indicate limits to the project of modernity, understood as a universalist, ethnocentric and positivist framework where certain norms and epistemologies are validated by hegemonic powers within the state and academia. In these hegemonic spaces ways of seeing have been developed which emphasize the inferiority of "the other" and the need to discipline them (see Castro-Gómez 1993: 152). The problem is not so much to do with the methods of modernity and its ways of organizing the world, but more the incontrovertible fact that such a project could not exist without its counterpart, rooted in the colonial encounter (see Escobar and Restrepo 2004), something directly relevant for countries with powerful colonial legacies, such as Guatemala.

Our collaborative practice with the indigenous authorities in Santa Cruz del Quiché provided new spaces to analyse tensions within the complex multicultural, interlegal reality of Guatemalan society. At the same time, this interaction also opened up a rich space for reflection on anthropological practice. The procedures filmed by nonprofessional indigenous cameramen in Quiché, and our efforts to turn them into videodocumentaries, represented then a unique opportunity to develop a shared or collaborative anthropological practice at the same time as offering new inputs to specific debates within social science and particularly within anthropology.

As I have signalled here, it is in these points of contact between different practices, interests and understandings of reality that such experiences can generate contributions to current debates about representation, collaboration and intertextuality, allowing in turn for the construction of texts where different voices and representations are combined in a single product, even though the uses it may be put to can be highly varied. In such exercises authors such as Stuart Hall have pointed to the need to think with social movements and to theorize from practice, recognizing that theory itself is a form of practice (cited in Restrepo et. al. 2010:12). This point is relevant because visual ethnographies are ultimately both academic and applied exercises. Much of our interactions pass through the crucible of intersubjectivities, interests and mutual positionings. This in turn is opening spaces for polyphonic ethnographies, which in some way contain the long term objectives of all the different participating actors. As Lizette Josephides observes, "our ethnographic strategies are also shaped by the subjects' 
situations, their global as well as local perceptions, and their demands and expectations of us" (quoted in Pink 2007: 5).

Video is particularly valuable for ethnographic research: first, it is a medium where texts can be codified and de-codified by almost anyone with minimal specialist training (although its readings will naturally vary). Second, it allows us to circumnavigate the written text, something which has been one of the most powerful tools for academic validation of different cultural realities, normally achieved through the authoritative voice of the anthropologist. With the aid of this electronic medium, individuals with limited literacy skills, but who have organizational talent and experience of leadership can structure and promote their vision of the world in novel ways. In this manner they can find new forms of social inclusion and recognition within spheres hitherto dominated by the written word, one of the primary mechanisms to establish hegemonic understandings of the world, together with laws and national identities (see Castro Gómez 1993: 148).

What is at stake then, is the possibility of structuring and socially validating practices where alternative epistemologies -in this case Mayan law and collaborative and intertextual video- can be articulated. Such ways of understanding reality should not be thought of as radically different or incommensurable with western norms. Instead the challenge lies in decentring the validation of knowledge production, and of social practices which occur at the margins of dominant culture, in order to locate them within broader conceptual frameworks where they can become more included within the hegemonic society.

\section{Intertextuality}

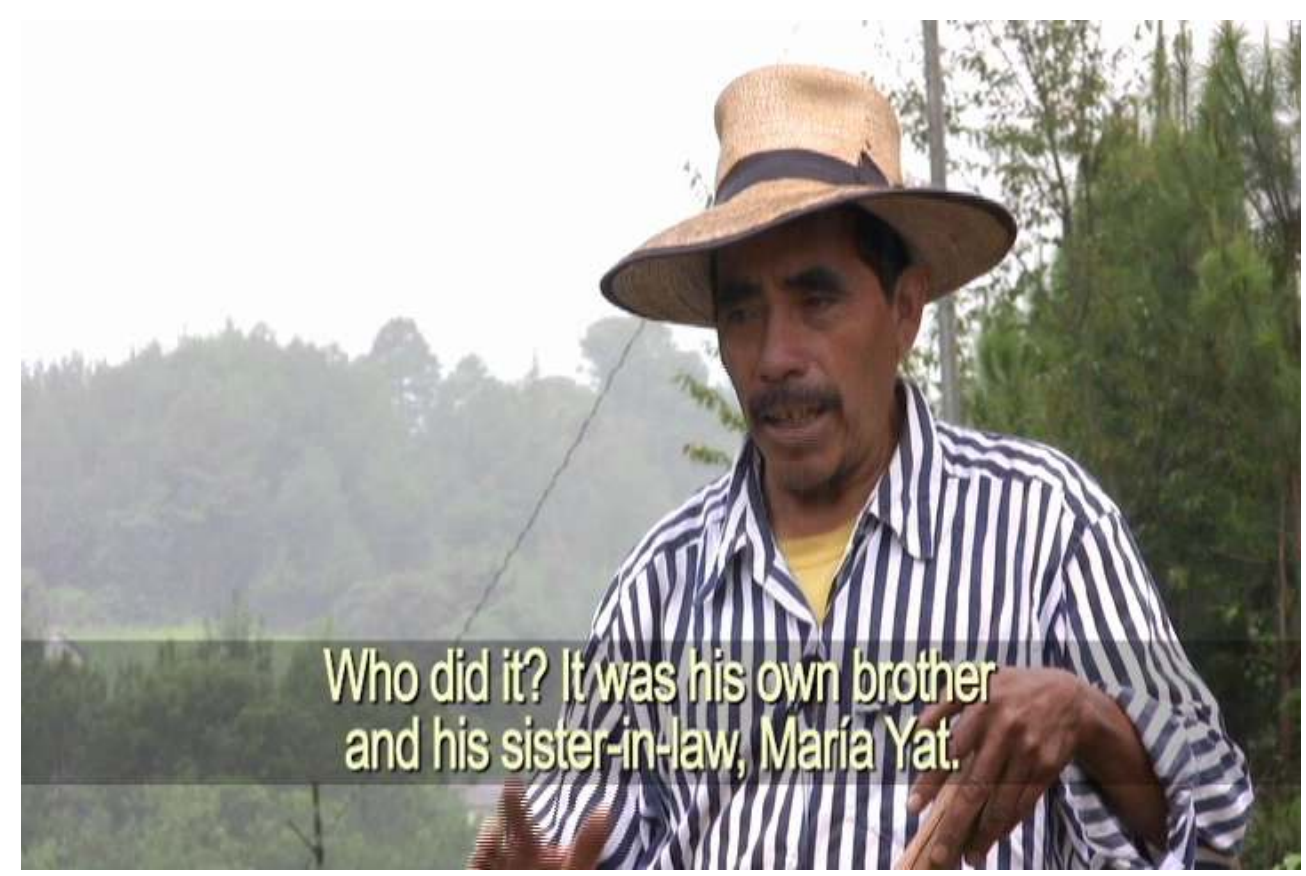

Still from "Two Justices" by Carlos Y. Flores 


\section{BIBLIOGRAPHY}

\section{Books and articles}

Castro-Gómez, Santiago. 1993. Violencia Epistémica y el Problema de la 'Invención del otro'. In La Colonialidad del Saber: Eurocentrismo y Ciencias Sociales. Perspectivas Latinoamericanas. Edgardo Lander, ed. Pp. 145-161. Buenos Aires: Consejo Latinoamericano de Ciencias Sociales, Clacso.

Clifford, James and George E Marcus. 1986. Writing Culture: The poetics and Politics of Ethnography. Berkeley: University of California Press.

de Sousa Santos, Boaventura. 2002. Toward a New Legal Common Sense. London: Butterworths.

Escobar, Arturo and Eduardo Restrepo. 2004. Antropologías en el Mundo. Jangwa Pana 3: 110-131. Santa Marta, Colombia: Programa de Antropología/Universidad del Magdalena.

Goldstein, Daniel M. 2002. Neo-liberal justice and self-help security in Bolivia. Critique of Anthropology 25, pp. 389-411. London: Sage Publications.

Hall, Stuart. 1997. Representation. The Open University. London: Sage Publications Ltd.

Hall, Stuart. 2010. Sin garantías: Trayectorias y problemáticas en estudios culturales. Bogotá: Instituto de estudios sociales y culturales Pensar, Universidad Javeriana.

Padilla, Guillermo. 2008. La Historia de Chico. Sucesos en Torno al Pluralismo Jurídico en Guatemala, un País Mayoritariamente Indígena. In Hacia Sistemas Jurídicos Plurales: Reflexiones y Experiencias de Coordinación entre el Derecho estatal y el Derecho indígena. Rudolf Huber, Juan Carlos Martínez et. al., eds. Pp. 151-186. Konrad Adenauer Stiftung. Bogotá, Colombia: Ediciones Antropos Ltda.

Pink, Sarah. 2007. Doing Visual Ethnography: Images, Media and Representation in Research. London: Sage Publications Ltd.

Poole, Deborah. 1997. Vision, Race and Modernity: A Visual Economy of the Andean Image World. Princeton, New Jersey: Princeton University Press.

PNUD-Guatemala (Programa de las Naciones Unidas para el Desarrollo). 2008. Informe Estadístico de la Violencia en Guatemala. Programa de Seguridad Ciudadana y Prevención de la Violencia del PNUD. Guatemala: Magna Terra Editores S. A.

Restrepo, Eduardo, Catherine Walsh y Víctor Vich. 2010. Práctica crítica y vocación política: pertinencia de Stuart Hall en los estudios culturales latinoamericanos. In Sin garantías: Trayectorias y problemáticas en estudios culturale., Pp. 7-14. Bogotá: Instituto de estudios sociales y culturales Pensar, Universidad Javeriana.

Risør, Helene. 2010. Twenty Hanging Dolls and a Lynching: Defacing Dangerousness and Enacting Citizenship in El Alto, Bolivia. Public Culture 22 (3): 465-485. Duke, North Carolina: Duke University Press.

Rojas Pérez, Isaías. 2008. Writing the Aftermath: Anthropology and 'Post-Conflict'. In A Companion to Latin American Anthropology. Deborah Poole, ed. Pp. 254-275, Oxford: Blackwell Publishing Ltd.

Said, Edward W. 1995. Orientalism. London: Penguin Books. 
Sieder, Rachel. 2011. Indigenous Law, Violence and State Effects in Postwar Guatemala. Critique of Anthropology, Vol. 31 (3): 161-84.

Sierra, María Teresa. 2004. Haciendo Justicia: Interlegalidad, derecho y género en regiones indígenas. México: CIESAS y Miguel Ángel Porrúa.

Turner, Victor. 1974. Dramas, Fields and Metaphors. NewYork: Ithaca.

Films

Flores, Carlos Y., dir. 2010. K'ixba'l (Shame). Casa Comal, Fundación Soros-Guatemala, Universidad Autónoma del Estado de Morelos, México (production). 37 min. Videolink: https:// vimeo.com/51473676

Flores, Carlos Y., dir. 2011. Two Justices: The Challenges of Interlegal Coordination. Casa Comal, Fundación Soros-Guatemala, Universidad Autónoma del Estado de Morelos, México (production). 39 min. Videolink: https://vimeo.com/51473674

\section{NOTES}

1. An earlier version of this article was published in Spanish in Íconos, Revista de Ciencias Sociales 42, FLACSO-Ecuador, 2012: 71-88. ISSN: 1390-1249.

2. In this case Petrona, the widow, demanded the death penalty for the accused once their guilt had been established. However, given that no such sanction exists in Mayan law, the assembly decided that the case should be turned over to the official justice system. The suspects were turned over to the public prosecutor's office, together with their filmed confession. Following a criminal investigation and trial they were sentenced to 50 years in prison for the murder.

3. The K'iche Defense was established after the 1996 peace agreements. It is a non-governmental organization of k'iche' community activists in the municipality of Santa Cruz del Quiché which offers free legal defense and conciliation services for people with limited economic means. It also works to foster coordination between state law and maya-k'iche' law. The K'iche' Defense was mostly funded through international development cooperation.

4. A report by the UN Development Program signals that Guatemala is one of the world's most violent countries that is officially "at peace" (PNUD: 2008). The UN calculates that rates of violence have increased by around 12 per cent per year since 1999, with the national homicide rate reaching approximately 50 for every 100,000 inhabitants. Over 90 per cent of these homicides are never formally investigated and just two per cent are sanctioned within the national justice system.

5. Deborah Poole has written about the value that mechanical images acquire when they are framed within a modern, realist western discourse where "use value" has to do with the ability to represent or reproduce reality (1997: 10).

6. One example of the kind of discussions and negotiations we had when deciding the final format of the visual text was when we proposed the title K'ixba'l ("Shame" in K'iche'), thinking that this summed up the meaning of the correction applied to the three young men depicted in the video. In contrast Juan Zapeta suggested a less abstract and more descriptive or direct title: "The robbery of a truck in the community of Choacamán resolved according to Mayan law". In the second documentary, Two Justices, the indigenous mayors asked us to stress the fact that they could have ended up being jailed for their participation as mediators in the conflict involving the widow Petrona Urízar. They were at pains to emphasize that ultimately the state justice officials had validated their legal practices and forms of law. 
7. However, the local population is aware that there are certain videos "which do lie": they have seen the ways in which certain cases can be manipulated and misrepresented, particularly when cameramen of local cable TV stations have recorded, edited and transmitted distorted reports about high profile cases resolved according to Mayan law.

8. Since the signing of the peace agreements in 1996 the summary, collective executions of at least 500 suspected criminals has been documented. Most of these have occurred in rural areas that were particularly badly affected by the counterinsurgency violence of previous years (Rojas 2008:257).

9. One only has to type "Guatemala" and "lynching" into the Youtube webpage to see graphic examples of this kind of summary execution, although these generally are examples of anonymous, mob violence which do not identify ringleaders.

10. The term vigilantes is used here to refer to non-legal organized groups who punish those who have supposedly broken the law, styling themselves as a kind of private or community police force (generally at the margins of the law).

11. Boaventura de Sousa Santos has similarly argued that legal pluralism cannot be understood as separate legal orders coexisting in the same political space, but rather -according to his much cited definition of "interlegality"- as "different legal spaces superimposed, interpenetrated and mixed as much in our minds as in our actions..." (2002: 437).

12. Authors such Stuart Hall talk about the need to work "inside" and "outside" of ethnicity, with the aim of developing a politics that can "be built with and through difference, able to construct those forms of solidarity and identification which make possible common struggles and resistances, and which do this without suppressing the real heterogeneity of interests and identities, and which can effectively draw the political boundaries without which political confrontation is impossible, without fixing those boundaries forever." (Hall 2010: 9).

13. These attempts to "fix" the historical record are not shared by everyone. During a public presentation of K'ixb'al in Guatemala City, a supporter of Mayan law working in another part of the country criticized our position, saying that as researchers we were not interested in how Mayan law should operate but rather in showing how it functioned in practice, with all its ensuing contradictions. He maintained that such a portrayal put Mayan law at a disadvantage with non-indigenous law, which always managed to maintain an ideal of the law despite the fact that this was not mirrored in practice. For this critic it was more strategic to discuss an ideal model of Mayan law rather than focus on its actual practice.

\section{ABSTRACTS}

Access to an archive of videos recording popular trials organized according to "Mayan law" filmed by indigenous people in Santa Cruz del Quiché, Guatemala, prompted the author to propose a collaborative video project with local indigenous mayors. This took place in a postwar region characterized by high levels of criminality and social violence, where the presence of state law was minimal or inexistent. The article discusses the possibilities and challenges of this collaborative project and emphasizes the uses of video in indigenous legal practices. It offers theoretical reflections on a range of issues, including legal pluralism, indigenous video, intertextuality and collaborative anthropology. 
L'accès à des archives vidéos, enregistrant des procès populaires organisés selon la "loi Maya" et filmées par des autochtones de Santa Cruz del Quiché, au Guatemala, a incité l'auteur à proposer un projet vidéo en collaboration avec des maires autochtones locaux. Cela s'est produit dans une région de l'après-guerre caractérisée par des niveaux élevés de criminalité et de violence sociale, où la présence du droit étatique était minimale ou inexistante. L'article examine les possibilités et les défis de ce projet de collaboration et met l'accent sur l'utilisation de la vidéo dans les pratiques juridiques autochtones. Il propose des réflexions théoriques sur toute une série de questions, dont le pluralisme juridique, la vidéo autochtone, l'intertextualité et l'anthropologie collaborative.

El acceso de un archivo de video registrando juicios populares dentro del llamado "derecho maya" y filmado por camarógrafos indígenas de Santa Cruz del Quiché, Guatemala, posibilitó que el autor propusiera un proyecto colaborativo de video con alcaldes indígenas locales. Lo anterior se llevó a cabo en una región de postguerra caracterizada por altos niveles de criminalidad y violencia social, donde la presencia del derecho oficial es mínima o inexistente. El artículo discute las posibilidades y dificultades de este proyecto colaborativo y enfatiza sobre los usos del video en prácticas legales indígenas. Ofrece reflexiones teóricas alrededor de varios temas, como el pluralismo legal, el video indígena, la intertextualidad y la antropología colaborativa.

\section{INDEX}

Mots-clés: droit autochtone, Guatemala, vidéo communautaire, pluralisme juridique, multiculturalisme, anthropologie collaborative, anthropologie visuelle, anthropologie juridique Palabras claves: derecho indígena, Guatemala, video comunitario, pluralismo legal, antropología colaborativa, antropología visual, antropología legal

Keywords: indigenous law, Guatemala, community video, legal pluralism, multiculturalism, collaborative anthropology, visual anthropology, legal anthropology.

\section{AUTHOR}

\section{CARLOS Y. FLORES}

Universidad Autónoma del Estado de Morelos, México, Department of Anthropology carlosyflores@aol.com

Carlos Y. Flores studied at the National School of Anthropology and History in Mexico and has a $\mathrm{PhD}$ in social anthropology from the University of Manchester, UK, where he specialized in visual anthropology at the Granada Centre for Visual Anthropology. He taught for a number of years as a visiting lecturer on the MA programme in Visual Anthropology in the Department of Anthropology at Goldsmiths College, University of London. He has published numerous articles on visual anthropology, political violence and processes of community reconstruction and access to the rule of law in the Maya region. He has also collaborated on indigenous community video projects in Guatemala, Chiapas and Mexico City. Carlos Y. Flores is a full time lecturer at the Department of Anthropology at the Autonomous University of the State of Morelos in Mexico. 